\title{
Utilization of Family Medicine Plant in Nias Islands, North Sumatra Province
}

\author{
Adam Smith Bago \\ Department of Biology, Faculty of Mathematics and Natural Sciences \\ STKIP Nias Selatan, Telukdalam 22865, North Sumatra, Indonesia. \\ ${ }^{*}$ Corresponding author: \\ Email: asmithbago@gmail.com
}

\begin{abstract}
.
Based on preliminary observations, it was found that the people in Nias Islands, North Sumatra province had used medicinal plants for a long time and had inherited them from generation to generation. So that many people still use medicinal plants. This study aims to determine the types of family medicinal plants used by the community, how to mix or process family medicinal plants, and public perceptions of family medicinal plants. This research is a type of qualitative research with descriptive methods with 125 respondents. Collecting data by observation, interviews, documentation. The data analysis technique uses three stages, namely data reduction, data presentation, and drawing conclusions or verification. From the research results, there were 23 plant species used by the community in Nias Island as Family Medicinal Plants. The method of concocting family medicinal plants varies greatly, depending on the type of plant and disease, the people of Sambulu village have good perceptions about family medicinal plants. Suggestions are expected to maintain the habit of using medicinal plants, and also teach them to children or young people.
\end{abstract}

Keywords: Utilization; Herbs; Family Medicinal Plants.

\section{INTRODUCTION}

Plants grow and live anywhere. They can be at home, garden or forest environment. Basically, plants can be used as a source of food, clothing, and also as medicine. In community life, plants are used as medicine for the treatment of all kinds of diseases. The use of plants as medicine has always been in demand by the village community. In addition, this is indicated by the number of traditional healing centers and many traditional medicinal products circulating among the community, which are commonly called herbs.

Herbs are plants that have medicinal properties. Herbs are an invaluable natural wealth of Indonesia. We often know as spices. Herbs can play a role in first aid for health problems and are proven to be effective in curing various diseases and even diseases that are almost incurable even though they still have a chance to be cured using herbal ingredients because herbal treatment is easier for the body to accept. That is why the recovery can be faster.

Herbs have been a legacy that has been going on for generations since ancient times. With the knowledge that has been passed down by their ancestors, until now, 
herbs have become the people's choice in curing diseases, and some even cultivate them as family medicinal plants.

Family medicinal plants are plants which are cultivated either in the yard, garden, house as a treatment for disease. Family medicinal plantsare used by the community as medicine. Because medicinal plants that are used as medicine have active ingredients or substances that function to prevent and treat diseases, both diseases caused by changes in weather or other diseases.

Utilization of family medicinal plantsis a community tradition in everyday life, where the use of medicinal plants as ingredients for the treatment of diseases has been deeply rooted in the midst of community life, especially those who live in villages.

One example of a traditional community that still maintains the customs and traditions of their ancestors in the use of natural resources in the form of medicinal plants is the people of Nias Islands, North Sumatra province. The Nias Islands region, North Sumatra province, is one of the people of the Nias Islands which is quite difficult to reach, because it is located far from the Regency and the capital and the roads are inadequate. This makes people use plants in the surrounding environment as medicinal ingredients, and some families even cultivate medicinal plants around their homes which are known as family medicinal plants.

However, along with the times and increasing health services, people switch to medical treatment, namely by using synthetic drugs. So that people rarely even don't take advantage of family medicinal plants. This makes the younger generation not aware of several types of medicinal plants. So, to anticipate that public knowledge about medicinal plants is not lost, the authors are interested in conducting research with the title "Utilization of Family Medicinal Plants in Nias Island North Sumatra.

\section{METHODS}

This research was conducted in Nias Islands, North Sumatra province in September - October 2018. This research is a type of qualitative research with a descriptive method where the research data is in the form of data on the types of family medicinal plants, how to use medicinal plants, and the perceptions of the people of Nias Islands, North Sumatra province. about the medicinal plant family. Sources of data collected in this study are primary data and secondary data. The data collection techniques used by researchers in this study were observation, interviews, and documentation. The data analysis technique used is data reduction, data presentation and conclusion / verification as well as checking the validity of the data used, namely triangulation.

\section{RESULT AND DISCUSSION}

Based on the results of research conducted in Nias Island, North Sumatera, information was obtained from 23 species of family medicinal plants, namely: 
1. Reed (Imperata cylindrical L.)

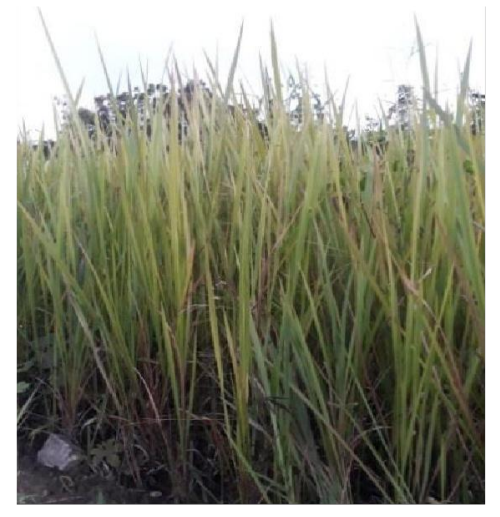

Reed (Imperata cylindrical L.) is known by the community in Sambulu village as O'o. Imperata is grass that is considered a weed. But behind that, this grass has extraordinary properties. The people of Nias Islands, North Sumatra province use reeds as a medicine for poisoning, difficulty urinating and body pain. Reeds can be found in gardens, fields, and vacant land.

\section{Bandotan (Ageratum conyzoides)}

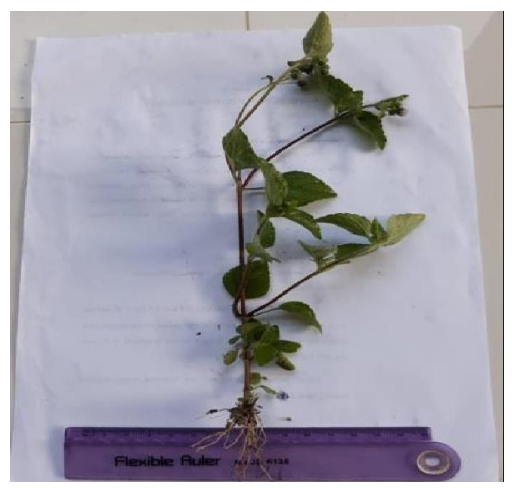

Bandotan (Ageratum conyzoides) is known by the community in Sambulu village as Ndru'u asu. Bandotan can live everywhere, so it's easy to get. Sambulu villagers use it as a malaria medicine.

\section{Gandarusa (Justicia gendarusa)}

Gandarusa (Justicia gendarusa) is known by the community in Sambulu village as Lio-lio. Gandarusa can be obtained by the community from gardens and is usually used as a barrier to plantations. The community of Sambulu village uses gandarusa as a medicine for body pain and rheumatism. 


\section{Slobber (Coleus scutellarioides)}

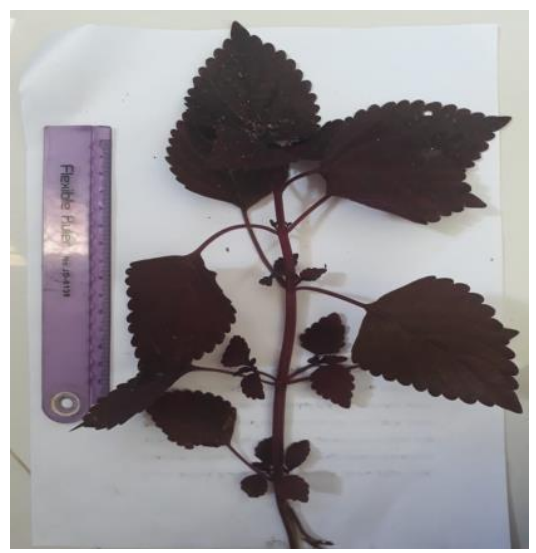

Slobber (Coleus scutellarioides L.) is known by the community in Sambulu village as Söfö- söfö soyo. Iler can be found in the yard of the house because this plant is usually used as a decoration or flower in the yard, because in addition to having benefits as a medicine, it also has good flowers. The Sambulu villagers use iler as a fever medicine.

\section{Ginger (Zingiber officinale Rosc)}

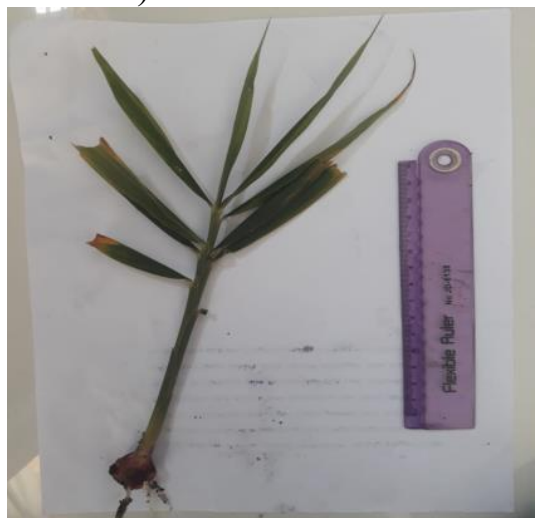

Ginger (Zingiber officinale Rosc) is known by the community in Sambulu village as Lahia. In addition to cooking ginger, the people of Sambulu village use ginger as colds, coughs and toothaches.

\section{Guava (Psidium guajava L.)}

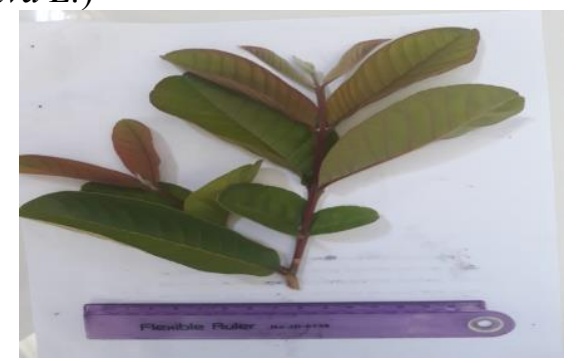

http://ijstm.inarah.co.id 
Guava (Psidium guajava L.) is known by the community in Sambulu village as Gabu. The community of Sambulu village uses it as a medicine for stomach aches and diarrhea.

\section{Lime (Citrus aurantifolia)}

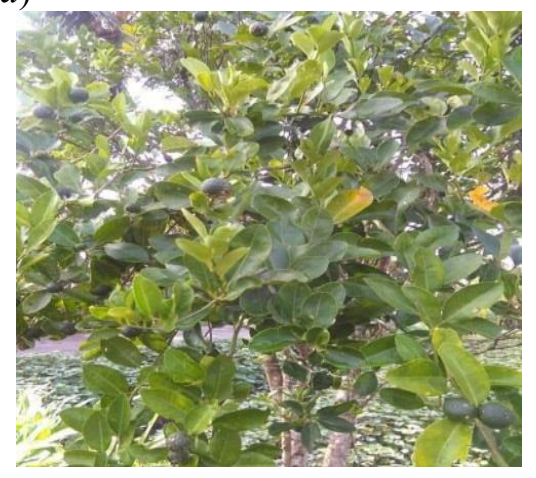

Lime (Citrus aurantifolia) is known by the community in Sambulu village as Ndrima sa'a. Sambulu villagers use it as a cough medicine.

\section{Cardamom (Amomum cardamomum)}

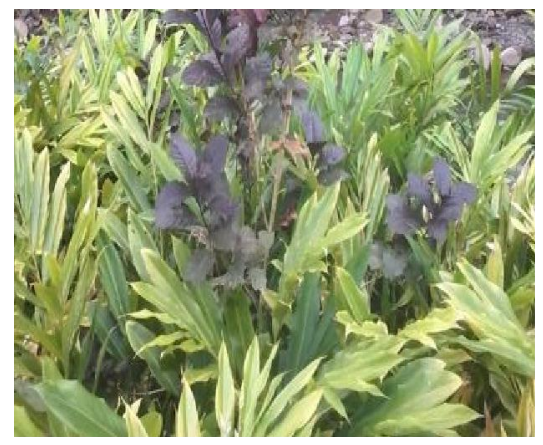

Cardamom (Amomum cardamomum) is known by the community in Sambulu village as Kafulaga. The community in Sambulu village uses it as a medicine for canker sores and fever.

9. Hibiscus (Hibiscus rosasinensis)

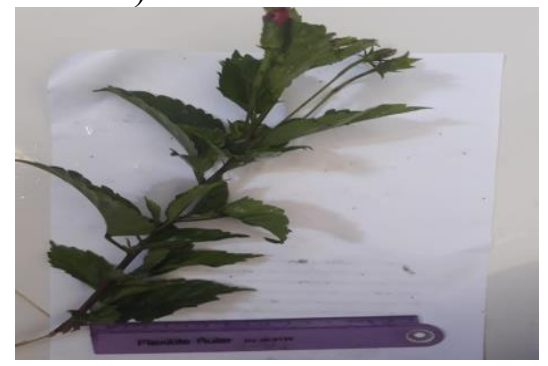

The hibiscus flower (Hibiscus rosasinensis) is known by the community in Sambulu village as Söma-söma. People use it as a medicine for poisoning and fever. 


\section{Coconut (Cocos nucifera)}

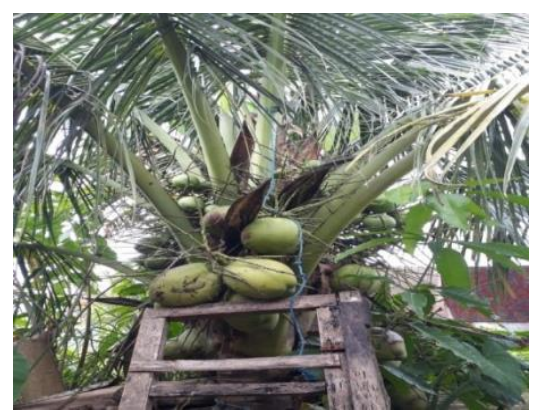

Coconut (Cocos nucifera) is known by the community in Sambulu village as Ohi while the fruit is called banio. Coconut has long been used by the community as medicine. the part used is the fruit. Coconut fruit consists of shells, meat, and coconut water. Coconut water is used by the community in Sambulu village as a medicine for heartburn, poisoning and chapped lips. According to Putra (2016: 100) "coconut is efficacious for treating poisoning, heartburn, fever, dengue fever, morbilli, influenza, urinary stones, pain during menstruation, pinworms, toothache, gray hair, and eliminating dandruff".

\section{Cat's whiskers (Orthosiphon aristatus)}

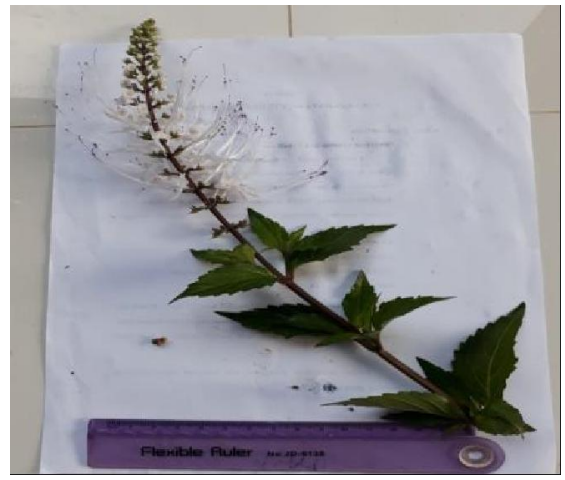

The cat whiskers (Orthosiphon aristatus) are known by the community in Sambulu village as Sogambi mao. The community uses it as a medicine for kidney stones and rheumatism.

12. Turmeric (Curcuma domestica L.)

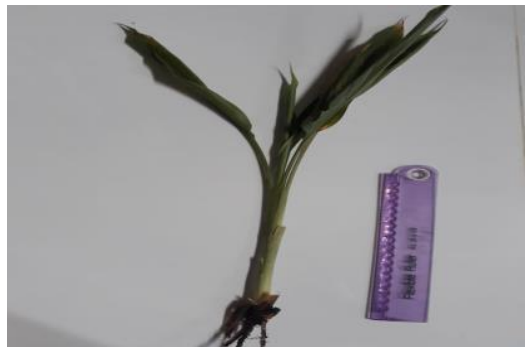


Turmeric (Curcuma domestica L.) is known by the community in Sambulu village as Undre. The community uses it as a medicine for coughs, colds and stomach aches.

13. The crown of the gods (Phaleria macrocarpha)

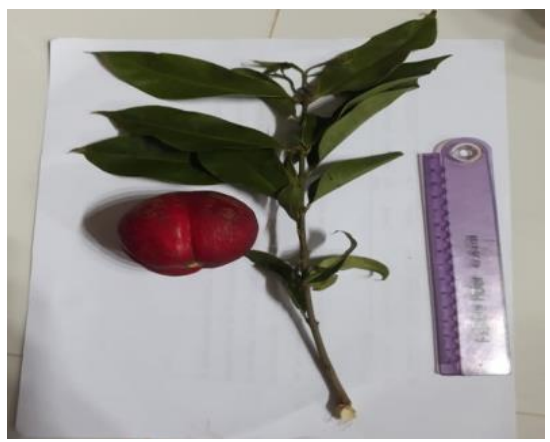

The crown of the gods (Phaleria macrocarpha) is known by the community in Sambulu village as Bua aka. People use it as a medicine for high blood pressure.

14. Noni (Morinda citrifolia L.)

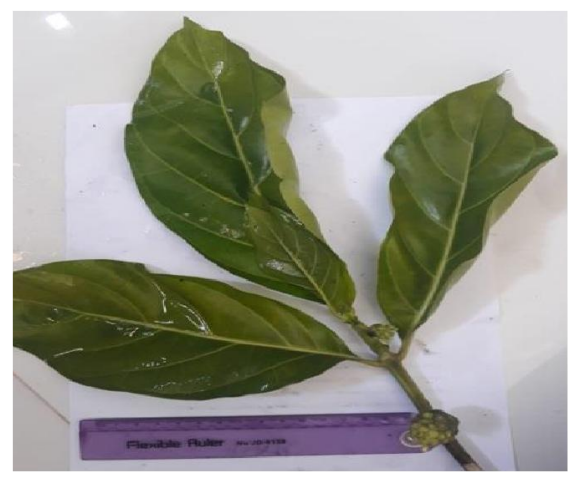

Noni (Morinda citrifolia L.) is known by the community in Sambulu village as Bua aka. People use it as a medicine for diabetes and high blood pressure.

\section{Meniran (Phyllanthus niruri L.)}

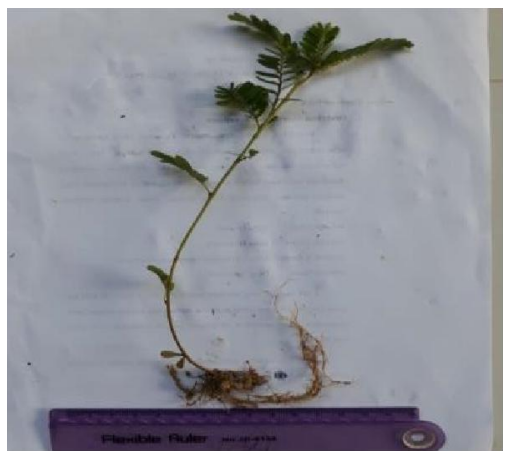


International Journal Of Science, Technology \& Management

Meniran (Phyllanthus niruri L.) is known by the community in Sambulu village as Sowua bagero. The community uses it as a medicine for kidney stones.

16. Cucumber (Cucumis sativus)

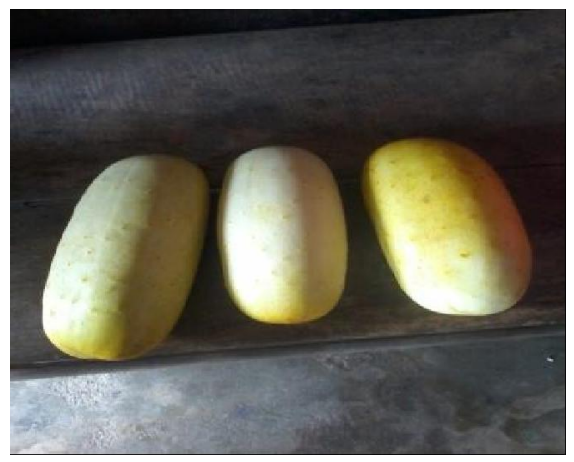

Cucumber (Cucumis sativus) is known by the community in Sambulu village as Laiju. The community of Sambulu village uses it as a medicine for high blood pressure.

17. Water girlfriend (Impatiens balsamine)

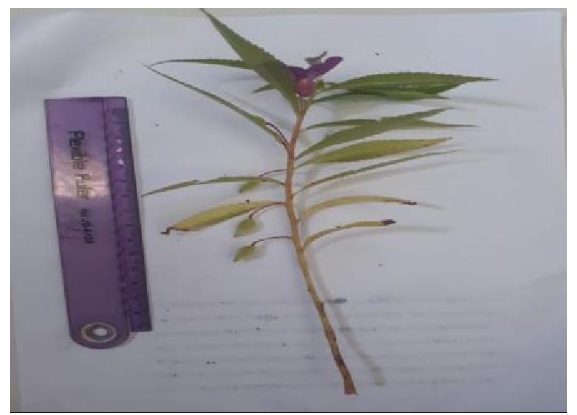

Water boyfriend (impatiens balsamina L.) is known by the community in Sambulu village as Hine. People use it as a medicine to vomit blood.

18. Ant nests (Myrmecodia pendans)

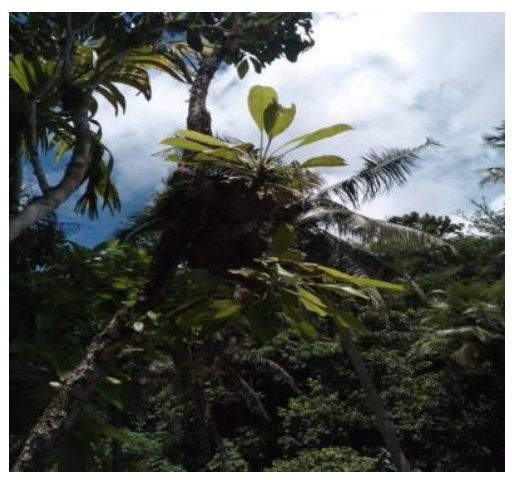


Ant nests (Myrmecodia pendans) are known by the community in Sambulu village as Binu mba'e. Ant nests are used by the community as a goiter medicine.

19. Green betel (Piper betle L.)

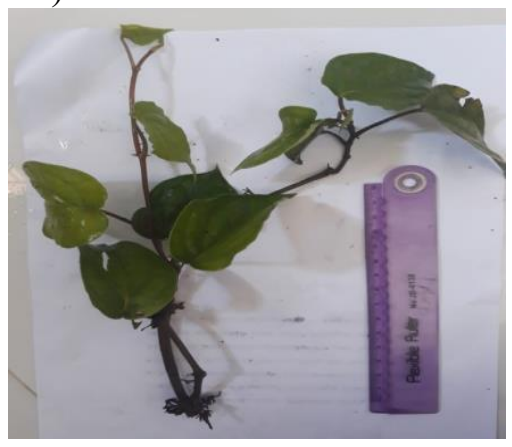

Green betel (Piper betle L.) is known by the community in Sambulu village as Tawuo niha. The people of Sambulu village use green betel as a medicine for eye pain, tonsillitis, and body odor.

20. Forest betel (Piper caducibracteum)

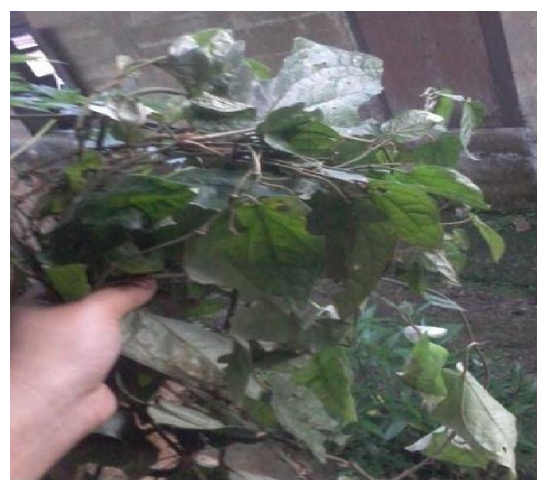

The forest betel (Piper caducibracteum) is known by the community in Sambulu village as Tawuo geu. The community in Sambulu village uses forest betel as a medicine for malaria and itching.

\section{Soursop (Annona muricata)}

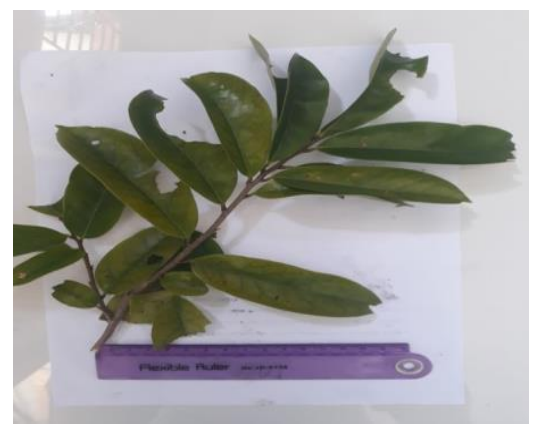


Soursop (Annona muricata L.), known by the community in Sambulu village as Garoto. The community of Sambulu village uses it as a medicine for high blood pressure.

\section{Duck bill (Kalanchoe pinnata)}

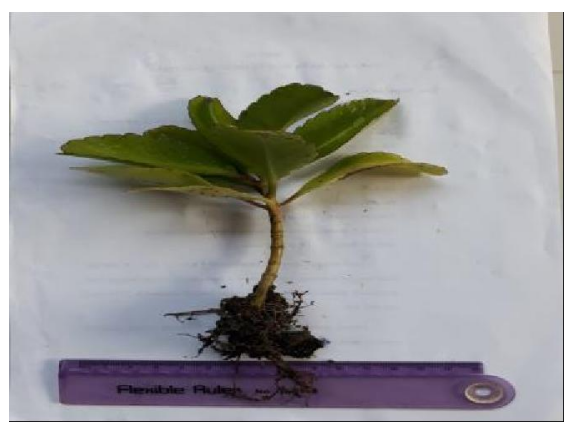

Sosor duck (Kalanchoe pinnata) is known by the community in Sambulu village as Bulu jakhoji. Sambulu villagers use it as a medicine for poisoning, heartburn, coughs, and fever.

\section{Suruhan (Peperomia pellucida)}

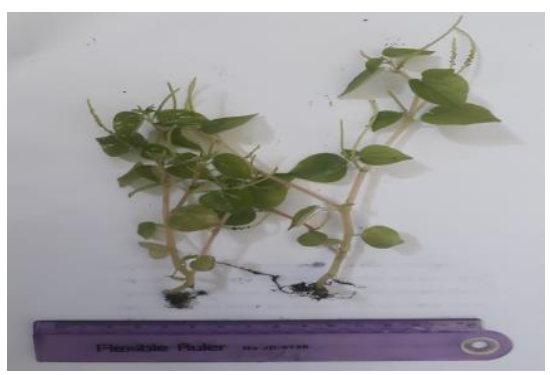

Suruhan (Peperomia pellucida) is known by the Nias Islands, North Sumatra province as Ndru'u sörömi. The villagers of Nias Islands, North Sumatra province use it as a medicine for poisoning and stomach aches.

\section{ACKNOWLEDGMENTS}

Based on the results of the study, it can be concluded that the family medicinal plants used by the people of Nias Islands, North Sumatra province, are known to be 23 species of plants used as medicinal ingredients. The plants commonly used by the community are Reed (Imperata cylindrical L.), bandotan (Ageratum conyzoides), gandarusa (Justicia gendarusa), slobber (Coleus scutellarioides), ginger (Zingiber officinale Rosc), guava (Psidium guajava L.), lime (Citrus aurantifolia), cardamom (Amomum cardamomum), hibiscus (Hibiscus rosasinensis), coconut (Cocos nucifera), cat's whiskers (Orthosiphon aristatus), turmeric (Curcuma domestica L.), crown of gods (Phaleria macrocarpha), noni (Morinda citrifolia L.), Meniran (Phyllanthus niruri L.), cucumber (Cucumis sativus), water henna (Impatiens balsamine), ant nests 
(Myrmecodia pendans), green betel (Piper betle L.), forest betel (Piper caducibracteum), soursop (Annona muricata), Duck bill (Kalanchoe pinnata), suruhan (Peperomia pellucida) The people of Nias Island, Nias Islands province, North Sumatra province mix or process medicinal plants for the family by mixing with other species and other ingredients such as such as salt, sugar, and egg yolk. This family medicinal plant can be used by boiling then drinking it or making it into bath water, pounding it and then drinking it or applying it, chewing it or eating it immediately, and squeezing the water and dropping it on the affected part. How to use it in accordance with the disease being treated. Parts of medicinal plants used as medicine are roots, leaves or young shoots, and stems.

According to the people of Nias Islands, North Sumatra province, family medicinal plants are better than synthetic medicines or medicines from hospitals. Apart from its non-toxic effects, family medicinal plants can be easily mixed / processed and easily obtained in the garden and also in the yard or around the house.

\section{REFERENCES}

[1] Adi, L. T. 2006. Tanaman Obat \& Jus Untuk Asam Urat \& Rematik. Jakarta Selatan. Penerbit PT AgroMedia Pustaka.

[2] Dalimartha, S. 2007. Atlas Tumbuhan Oba Indonesia Jilid 2. Jakarta. Penerbit Trubus Agriwijaya.

[3] Emzir. 2012. Metodologi Penelitian Kualitatif Analisis Data. Jakarta. Penerbit Rajawali.

[4] Fitriana, R. 2008. Mengenal Tumbuhan. Bandung. Penerbit Putra Setia.

[5] Fitriana, T. 2008. Membiasakan Hidup Sehat. Bandung. Penerbit PT. Puri Pustaka.

[6] Handayani, T. 2013. Apotek Hidup. Penerbit Padi.

[7] Handayani, A. 2015. Pemanfaatan tumbuhan obat oleh masyarakat Sekitar Cagar Alam Gunung Simpang, Jawa Barat, (Online), Vol. 1, No. 6.

[8] Kariman. 2014. Bebas Penyakit dengan Tanaman Ajaib. Surakarta: Penerbit Openbooks.

[9] Murtie, A. 2013. Kupas Tuntas Pengobatan Tradisional. Yogyakarta: Trans Idea Publishing.

[10] Ningrum, E. K. Meymurtie. 2012. Obat Tradisional Bayi, Balita, Dan Anak. Jakarta Timur. Dunia Sehat.

[11] Pranata, T. S. 2013. Herbal TOGA. Yogyakarta: Penerbit Aksara Sukses.

[12] Putra, W.S. 2016. Kitab Herbal Nusantara. Yogyakarta. Penerbit katahati.

[13] Riyanto, Y. 2010. Metodologi Penelitian Pendidikan. Surabaya: Penerbit SIC.

[14] Sasmito, E. 2017. Imunomodulator Bahan Alami. Yogyakarta: Rapha Publising. 